\title{
Obstetric Management of COVID-19 in Pregnant Women
}

\author{
Youwen $\mathrm{Mei}^{\dagger}$, Dan Luo ${ }^{\dagger}$, Sumei Wei, Xiaoyan Liao, Yue Pan, Xiao Yang and Yonghong Lin*
}

Department of Obstetrics and Gynecology, Chengdu Women and Children's Central Hospital Affiliated to University of Electronic Science and Technology of China, Chengdu, China

The 2019 novel coronavirus disease (COVID-19), which is caused by the novel beta coronavirus, SARS-CoV-2, is currently prevalent all over the world, causing thousands of deaths with relatively high virulence. Like two other notable beta coronaviruses, severe acute respiratory syndrome coronavirus-1 (SARS-CoV-1) and Middle East respiratory syndrome coronavirus (MERS-CoV), SARS-CoV-2 can lead to severe contagious respiratory disease. Due to impaired cellular immunity and physiological changes, pregnant women are susceptible to respiratory disease and are more likely to develop severe pneumonia. Given the prevalence of COVID-19, it is speculated that some pregnant women have already been infected. However, limited data are available

OPEN ACCESS

Edited by:

Sunil Kumar Lal,

Monash University Malaysia, Malaysia

Reviewed by: Anand K. Ramasubramanian, San Jose State University, United States Nathalie Pradel, Institut de Recherche Pour le Développement (IRD), France

${ }^{*}$ Correspondence: Yonghong Lin 381001243@qq.com

†These authors have contributed equally to this work

Specialty section:

This article was submitted to

Infectious Diseases,

a section of the journal

Frontiers in Microbiology

Received: 11 March 2020

Accepted: 11 May 2020

Published: 26 May 2020

Citation:

Mei Y, Luo D, Wei S, Liao X, Pan Y, Yang $X$ and Lin $Y$ (2020) Obstetric Management of COVID-19 in

Pregnant Women.

Front. Microbiol. 11:1186.

doi: 10.3389/fmicb.2020.01186 for the clinical course and management of COVID-19 in pregnancy. Therefore, we conducted this review to identify strategies for the obstetric management of COVID-19. We compared the clinical course and outcomes of COVID-19, SARS, and MERS in pregnancy and discussed several drugs for the treatment of COVID-19 in pregnancy.

Keywords: COVID-19, perinatal outcome, antiviral drug, vertical transmission, severe acute respiratory syndrome, Middle East respiratory syndrome, obstetric management

\section{INTRODUCTION}

The COVID-19 outbreak emerged in 2019. The causative pathogen for COVID-19 was identified as a novel beta coronavirus, SARS-CoV-2, which is genetically related to severe acute respiratory syndrome coronavirus-1 (SARS-CoV-1) and Middle East respiratory syndrome coronavirus (MERS-CoV; Lu et al., 2020). Furthermore, SARS-CoV-2 and SARS-CoV-1 share the same cellular receptor, angiotensin-converting enzyme 2 (ACE2), despite amino acid variation at some key residues (Chan et al., 2020). All three coronaviruses can cause severe infectious respiratory disease. Currently, COVID-19 has spread across multiple countries (Holshue et al., 2020; Hui et al., 2020), and it is reasonable to speculate that some pregnant women have been infected. However, little is known about the clinical course and the obstetric management of COVID-19 in pregnancy. Available data could be drawn from cases of pregnancy complicated with SARS and MERS. This review was conducted to investigate the clinical course and outcome of COVID-19 in pregnancy and to discuss several drugs that could be used for pregnant women with COVID-19.

\section{COMPARISON OF COVID-19, SARS, AND MERS IN PREGNANCY}

We searched PubMed and the China National Knowledge Infrastructure Database for literature that was published up to March 30, 2020, using the keywords “coronavirus," "pregnant," or "neonate." Data about pregnancy with COVID-19, SARS, and MERS were extracted and compared by gestational age. Table 1 shows maternal clinical characteristics, and Table 2 shows treatment and perinatal outcomes of the three coronavirus infections in pregnancy. 
Twenty-nine cases of COVID-19 during pregnancy were found in five reports (Chen H. et al., 2020; Chen S. et al., 2020; Yu et al., 2020; Zhao et al., 2020; Zhu et al., 2020). One patient was infected in the second trimester (Zhao et al., 2020), and the others in the third trimester (Chen H. et al., 2020; Chen S. et al., 2020; Yu et al., 2020; Zhu et al., 2020). The pregnant woman infected in the second trimester had symptoms of fever, cough, malaise, and subsequently dyspnea. Blood counts showed lymphopenia, and computed tomography $(\mathrm{CT})$ revealed diffused bilateral infiltrates in the lungs. She was given lopinavir/ritonavir, interferon $\alpha-2 b$, methylprednisolone, abidol, and gamma globulin successively. After 18 days of treatment, her condition improved, and virus nucleic acid testing for SARS-CoV-2 was negative twice. Thus, she continued with the pregnancy. On the other hand, the main symptoms of the other 28 patients infected in the third trimester were fever $(89.3 \%)$, cough $(35.7 \%)$, and myalgia (14.3\%). CT images of 27 patients showed multiple patchy ground-glass shadows in the lungs. Three patients had elevated liver enzymes and nine developed fetal distress. In 17 patients who had detailed treatment data, all patients received oxygen support via a nasal cannula, 14 patients underwent antiviral therapy, and 16 patients underwent antibiotic treatment. As a result, 26 patients delivered via cesarean section and two patients via vaginal delivery. All neonates survived except for one. It should be noted that in the study by Zhu et al. some neonates born to mothers with COVID-19 had adverse neonatal outcomes such as premature labor, respiratory distress, thrombocytopenia accompanied by abnormal liver function, and even death (Zhu et al., 2020).

With regard to SARS, 19 cases have been reported during pregnancy (Zhang et al., 2003; Robertson et al., 2004; Wong et al., 2004; Yudin et al., 2005). Seven patients became infected in the first trimester, five patients in the second trimester, and seven patients in the third trimester. The most common symptoms of infected pregnant women included fever (100\%), cough (78.9\%), and myalgia (68.4\%). Lymphocytopenia was observed in 15 pregnant women, and chest radiographs of all pregnant women indicated viral infection in the lungs. Twelve pregnant women were given antiviral drugs, 14 pregnant women were given antibiotic drugs, and 12 pregnant women were given corticosteroids. Spontaneous miscarriage was observed in four out of seven patients who were infected in the first trimester. Three of the 19 pregnant women died; however, all the neonates who were delivered in the second or third trimester survived. Two cases suffered from fetal growth restriction and oligohydramnios, four cases developed fetal distress, and there was one case of spontaneous preterm birth.

Eleven cases of pregnancy with MERS were reported (Payne et al., 2014; Alserehi et al., 2016; Assiri et al., 2016; Malik et al., 2016; Park et al., 2016; Alfaraj et al., 2019). One patient was infected in the first trimester, five patients in the second

\footnotetext{
Abbreviations: GA, gestational age; COVID-19, 2019 novel coronavirus disease; SARS, severe acute respiratory syndrome coronavirus; MERS, Middle East Respiratory Syndrome coronavirus; CoV, coronavirus; ACE2, angiotensinconverting enzyme 2; HIV, human immunodeficiency virus; CT, computed tomography; CTG, cardiotocography; PROM, premature rupture of membranes; DIC, disseminated intravascular coagulation; IUGR, intrauterine growth retardation; HIV, human immunodeficiency virus; N/A, not available.
}

trimester, and six patients in the third trimester. Most pregnant women presented with dyspnea (72.7\%), cough (63.6\%), and fever $(54.5 \%)$; their chest radiographs revealed typical signs of viral infection. Unfortunately, there were no detailed treatmentrelated data. The woman infected in the first trimester continued pregnancy after her virus nucleic acid testing for MERS-Cov turned negative. Two patients had stillbirths, and one patient developed placental abruption. Three pregnant women and three neonates died.

\section{DIAGNOSIS AND TREATMENT OF COVID-19 IN PREGNANCY}

The diagnosis of COVID-19 in pregnancy is mainly based on epidemiological history, clinical manifestations, chest radiography, and etiological tests (National Health Commission of the People's Republic of China, 2020). This is similar to the evidence of diagnosis for SARS and MERS in pregnancy. According to our literature review, most pregnant women infected by the three coronaviruses had an epidemiological contact history. Fever, cough, myalgia, and dyspnea are the major symptoms. CT images revealed typical signs of viral infection in the lungs. Nasopharynx swab or sputum was positive in the virus nucleic acid test. Lymphopenia and elevated liver enzymes were commonly seen in pregnant women with COVID-19 and SARS.

According to the seventh guidelines published by the National Health Commission of China, the treatment of COVID-19 mainly involves oxygen therapy, antiviral therapy, and supportive treatment (National Health Commission of the People's Republic of China, 2020). At present, there is no antiviral drug for the treatment of COVID-19; therefore, identifying an antiviral drug against COVID-19 in pregnancy is imperative.

Interferon-alpha is a broad-spectrum antiviral drug that activates antiviral protein genes and modulates immune cell function (Totura and Bavari, 2019). For SARS-CoV-1 and MERS$\mathrm{CoV}$, interferon-alpha was effective at reducing viral replication in vitro and in vivo (Cinatl et al., 2003; Falzarano et al., 2013a,b). Regarding its safe use in pregnant women, one systematic review suggested that interferon-alpha does not significantly increase the risk of adverse perinatal outcomes above general population rates (Yazdani Brojeni et al., 2012).

Lopinavir/ritonavir is a human immunodeficiency virus (HIV) protease inhibitor that was found to target the SARS$\mathrm{CoV}-1$ nonstructural protein 3CLpro in vitro (Lu, 2020). During the SARS-CoV-1 epidemic, lopinavir/ritonavir combined with ribavirin reduced the viral load and decreased the rate of death or ARDS (Chu et al., 2004). Lopinavir/ritonavir also increased the viral clearance rate and survival rate in patients with MERS (Chan et al., 2015). Lopinavir/ritonavir was also administered to pregnant women with HIV. It was found that HIV proliferation was effectively suppressed during pregnancy and through 1 year postpartum (Cohan et al., 2015). Furthermore, the rate of preterm deliveries, low-birth-weight neonates, stillbirths, and birth defects did not increase (Roberts et al., 2009; Cohan et al., 2015). 
TABLE 1 | Maternal clinical and laboratory characteristics of COVID-19, SARS, and MERS in pregnancy.

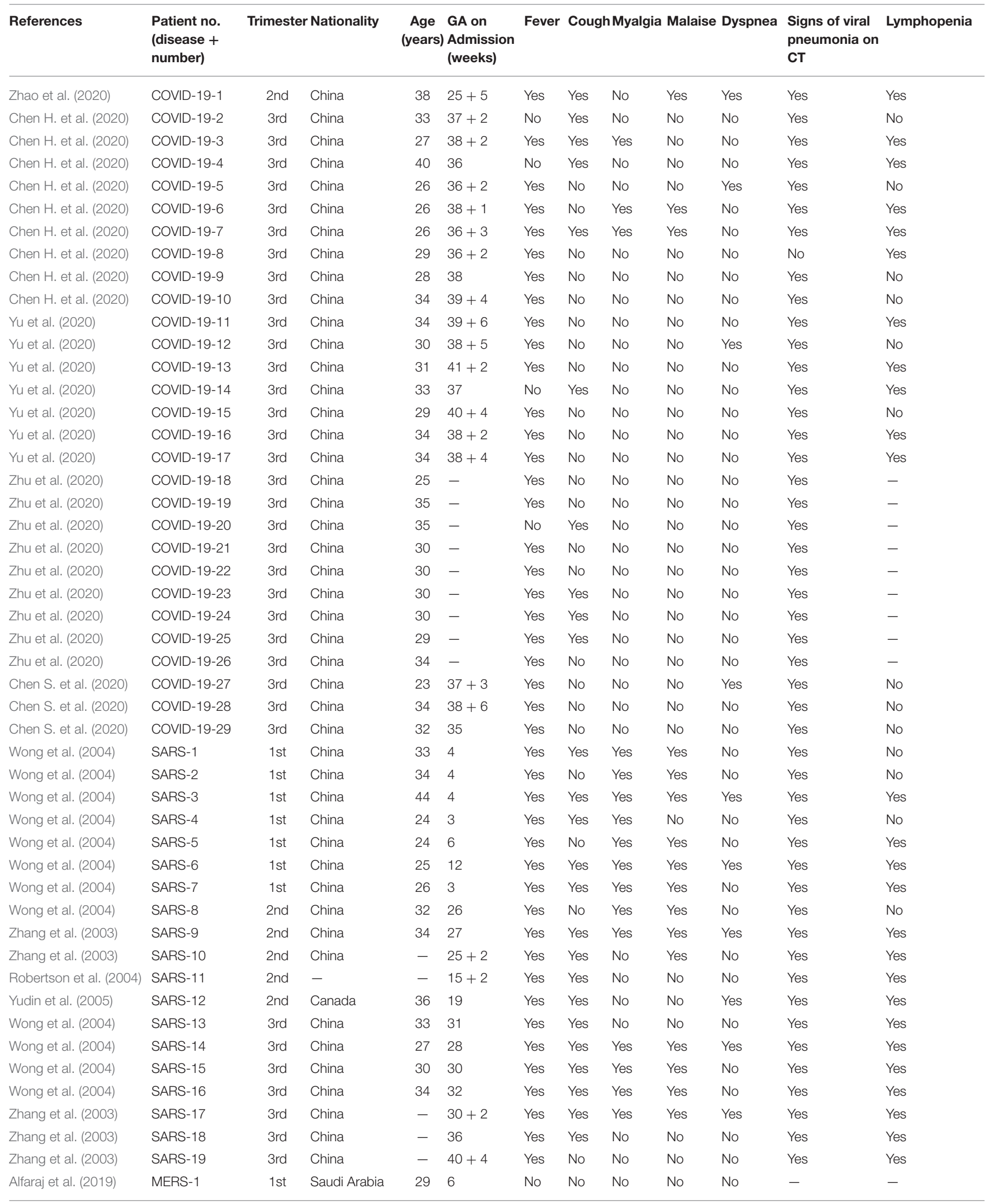


TABLE 1 | Continued

\begin{tabular}{|c|c|c|c|c|c|c|c|c|c|c|c|c|}
\hline References & $\begin{array}{l}\text { Patient no. } \\
\text { (disease + } \\
\text { number) }\end{array}$ & Trimeste & r Nationality & $\begin{array}{c}\text { Age } \\
\text { (years) }\end{array}$ & $\begin{array}{l}\text { GA on } \\
\text { Admission } \\
\text { (weeks) }\end{array}$ & Fever & Cough & Myalgia & Malaise & Dyspnea & $\begin{array}{l}\text { Signs of viral } \\
\text { pneumonia on } \\
\text { CT }\end{array}$ & Lymphopenia \\
\hline Payne et al. (2014) & MERS-2 & 2nd & Jordanian & 39 & 5 months & Yes & Yes & No & Yes & No & - & - \\
\hline Assiri et al. (2016) & MERS-3 & 2nd & Saudi Arabia & 27 & 22 & Yes & Yes & No & No & Yes & Yes & - \\
\hline Assiri et al. (2016) & MERS-4 & 2nd & Saudi Arabia & 30 & 23 & Yes & Yes & No & No & Yes & - & - \\
\hline Alfaraj et al. (2019) & MERS-5 & 2nd & Saudi Arabia & 39 & 24 & No & No & No & No & No & - & - \\
\hline Assiri et al. (2016) & MERS-6 & 2 nd & Saudi Arabia & 31 & 24 & No & Yes & Yes & No & Yes & Yes & - \\
\hline Alserehi et al. (2016) & MERS-7 & 3rd & Saudi Arabia & 33 & 31 & Yes & Yes & No & No & Yes & Yes & - \\
\hline Malik et al. (2016) & MERS-8 & 3rd & $\begin{array}{l}\text { United Arab } \\
\text { Emirates }\end{array}$ & 32 & 32 & Yes & Yes & No & No & Yes & Yes & - \\
\hline Assiri et al. (2016) & MERS-9 & 3rd & Saudi Arabia & 34 & 34 & No & No & No & No & Yes & Yes & - \\
\hline Park et al. (2016) & MERS-10 & 3rd & South Korean & 39 & $35+4$ & No & No & Yes & No & No & Yes & - \\
\hline Assiri et al. (2016) & MERS-11 & 3rd & Saudi Arabia & 32 & 38 & Yes & Yes & No & No & Yes & Yes & - \\
\hline
\end{tabular}

GA, gestational age; COVID-19, 2019 novel coronavirus disease; SARS, severe acute respiratory syndrome coronavirus; MERS, Middle East Respiratory Syndrome coronavirus; CT, computed tomography; -, no data.

In addition, ribavirin and favipiravir are representative of a guanosine analog. Mechanically, ribavirin and favipiravir can inhibit virus RNA synthesis by viral RNA-dependent RNA polymerase and inhibit mRNA capping (Totura and Bavari, 2019). In the previous literature, ribavirin was administered to pregnant women with SARS. However, it was found that ribavirin at the concentration of typical human regimens could not significantly inhibit coronavirus replication in vitro (Shen et al., 2016). Furthermore, meta-analyses have found that its role was limited in the treatment of coronavirus-related respiratory syndromes (Stockman et al., 2006; Morra et al., 2018). The resistance might be explained by nsp14 exoribonuclease being expressed by coronavirus. As nsp14 exoribonuclease can function as an excision nucleoside analog due to its proofreading activity (Minskaia et al., 2006), it is speculated that COVID-19 might also be resistant to ribavirin or favipiravir (Chan et al., 2020).

In contrast, remdesivir, a nucleoside analog, could act against both SARS-CoV-1 and MERS-CoV in vitro (Sheahan et al., 2017). In vivo, remdesivir was more effective than lopinavir/ritonavir combined with interferon- $\beta$ in decreasing the viral load of mice infected with MERS-CoV (Sheahan et al., 2020). The mechanism involved is that it can interfere with the nsp12 polymerase even in the setting of nsp14 exoribonuclease proofreading activity (Agostini et al., 2018). As expected, remdesivir was proved to be effective in the inhibition of SARS-CoV-2 replication in vitro (Wang et al., 2020a). However, data about its safety during pregnancy are absent.

Initially, chloroquine was used as an antimalarial drug. It was later found to act against SARS-CoV-1 in primate cells either before or after exposure to the virus (Vincent et al., 2005). Recently, chloroquine was found to inhibit the proliferation of SARS-CoV-2 in vitro (Wang et al., 2020a). The mechanism involved might be that it interferes with terminal glycosylation of ACE2 (Vincent et al., 2005). As to its safety in pregnancy, chloroquine was not shown to be associated with birth weight, gestational age, growth, or development of newborns, neurological development, and visual acuity in infants in the previous literature (Villegas et al., 2007; Ward et al., 2007; Divala et al., 2018).

Arbidol, which is a broad-spectrum antiviral drug whose mechanism involves inhibition of enveloped virus membrane fusion, has also been used (Blaising et al., 2014). Arbidol and arbidol mesylate were effective in suppressing the proliferation of SARS-CoV-1 in vitro (Khamitov et al., 2008). Furthermore, arbidol was effective against SARS-CoV-2 in vitro (Wang et al., 2020b). In Russia, arbidol was administered to pregnant women with influenza (Bulgakova et al., 2017). In our the studies included in our literature review, arbidol was found to have been administered to pregnant women with COVID-19 (Yu et al., 2020; Zhao et al., 2020). However, its safety in pregnancy requires further research.

In summary, interferon-alpha, lopinavir/ritonavir, and chloroquine could be administered to pregnant women with COVID-19 after patients were fully informed of these drugs' benefits and risks. Remdesivir and arbidol are promising antiviral drugs against COVID-19; however, their safety in pregnancy requires further research. In addition, antibiotics and corticosteroids are recommended in pregnancy with COVID-19 if necessary (Mer and Richards, 1998; Wong et al., 2003). However, antibiotics should not be used without indication, and high doses of glucocorticoids should be avoided as much as possible (National Health Commission of the People's Republic of China, 2020).

\section{PERINATAL OUTCOMES OF COVID-19 IN PREGNANCY}

Due to impaired cellular immunity and physiological changes, mild pneumonia is more likely to develop into severe pneumonia in pregnant women, and severe pneumonia is deleterious for the fetus (Lam et al., 2004; Goodnight and Soper, 2005). Thus, timely pregnancy termination may be beneficial for both mothers and infants if the disease advances. As to the mode of pregnancy 
TABLE 2 | Treatment and perinatal outcomes of COVID-19, SARS, and MERS in pregnancy.

\begin{tabular}{|c|c|c|c|c|c|c|c|c|c|}
\hline Patient no. & $\begin{array}{l}\text { GA of } \\
\text { delivery }\end{array}$ & $\begin{array}{l}\text { Antiviral } \\
\text { therapy }\end{array}$ & $\begin{array}{l}\text { Antibiotic } \\
\text { therapy }\end{array}$ & $\begin{array}{l}\text { Use of } \\
\text { corticosteroid }\end{array}$ & Delivery mode & $\begin{array}{l}\text { Complication } \\
\text { during pregnancy }\end{array}$ & $\begin{array}{l}\text { Indication of } \\
\text { C-section }\end{array}$ & $\begin{array}{l}\text { Maternal } \\
\text { outcome }\end{array}$ & $\begin{array}{l}\text { Neonatal } \\
\text { outcome }\end{array}$ \\
\hline COVID-19-1 & & Yes & No & Yes & - & - & - & Survived & $\begin{array}{l}\text { Ongoing } \\
\text { pregnancy }\end{array}$ \\
\hline COVID-19-2 & $37+3$ & Yes & Yes & No & Cesarean section & $\begin{array}{l}\text { Severely elevated } \\
\text { liver enzymes }\end{array}$ & COVID-19 & Survived & Survived \\
\hline COVID-19-3 & $39+1$ & Yes & Yes & No & Cesarean section & - & COVID-19 & Survived & Survived \\
\hline COVID-19-5 & $36+5$ & No & Yes & No & Cesarean section & Pre-eclampsia & $\begin{array}{l}\text { Pre-eclampsia; } \\
\text { COVID-19 }\end{array}$ & Survived & Survived \\
\hline COVID-19-6 & $38+2$ & No & Yes & No & Cesarean section & Fetal distress & $\begin{array}{l}\text { Fetal distress; } \\
\text { COVID-19 }\end{array}$ & Survived & Survived \\
\hline COVID-19-7 & 37 & No & Yes & No & Cesarean section & - & $\begin{array}{l}\text { History of stillbirth (x } \\
\text { 2); COVID-19 }\end{array}$ & Survived & Survived \\
\hline COVID-19-10 & $40+3$ & Yes & Yes & No & Cesarean section & PROM & PROM; COVID-19 & Survived & Survived \\
\hline COVID-19-11 & 40 & Yes & Yes & Yes & Cesarean section & - & Mature; COVID-19 & Survived & Survived \\
\hline COVID-19-12 & $38+5$ & Yes & Yes & Yes & Cesarean section & $\begin{array}{l}\text { Elevated liver } \\
\text { enzymes }\end{array}$ & $\begin{array}{l}\text { Mature; Precious } \\
\text { fetus; Placentas } \\
\text { racquet }\end{array}$ & Survived & Survived \\
\hline COVID-19-13 & $41+5$ & Yes & Yes & Yes & Cesarean section & Fetal distress & $\begin{array}{l}\text { Mature; Fetal } \\
\text { distress; COVID-19 }\end{array}$ & Survived & Survived \\
\hline COVID-19-14 & 37 & Yes & Yes & Yes & Cesarean section & - & $\begin{array}{l}\text { Mature; History of } \\
\text { C-section }\end{array}$ & Survived & Survived \\
\hline COVID-19-15 & $40+6$ & Yes & Yes & No & Cesarean section & - & $\begin{array}{l}\text { Mature; Failure trial } \\
\text { vaginal }\end{array}$ & Survived & Survived \\
\hline COVID-19-20 & $34+2$ & - & - & - & Vaginal delivery & PROM; fetal distress & - & Survived & Survived \\
\hline COVID-19-21 & $34+5$ & - & - & - & Cesarean section & - & - & Survived & died \\
\hline COVID-19-22 & 39 & - & - & - & Cesarean section & $\begin{array}{l}\text { Cholecystitis; fetal } \\
\text { distress }\end{array}$ & - & Survived & Survived \\
\hline COVID-19-23 & 37 & - & - & - & Cesarean section & $\begin{array}{l}\text { Fetal distress; } \\
\text { polyhydramnios }\end{array}$ & - & Survived & Survived \\
\hline COVID-19-24 & $34+6$ & - & - & - & Cesarean section & Fetal distress & - & Survived & Survived \\
\hline COVID-19-25 & 31 (Twin) & - & - & - & Vaginal delivery & Fetal distress & - & Survived & Survived \\
\hline COVID-19-26 & 39 & - & - & - & Cesarean section & - & - & Survived & Survived \\
\hline COVID-19-27 & $37+4$ & - & - & - & Cesarean section & $\begin{array}{l}\text { Complete placenta } \\
\text { previa }\end{array}$ & - & Survived & Survived \\
\hline COVID-19-28 & 39 & - & - & - & Cesarean section & $\begin{array}{l}\text { Acute cholecystitis, } \\
\text { placental abruption }\end{array}$ & - & Survived & Survived \\
\hline COVID-19-29 & 35 & - & - & - & Cesarean section & $\begin{array}{l}\text { Complete placenta } \\
\text { previa }\end{array}$ & - & Survived & Survived \\
\hline SARS-1 & 2 & Yes & Yes & Yes & - & - & - & Survived & $\begin{array}{l}\text { spontaneous } \\
\text { abortion }\end{array}$ \\
\hline SARS-2 & 3 & Yes & Yes & Yes & - & - & - & Survived & $\begin{array}{l}\text { Spontaneous } \\
\text { abortion }\end{array}$ \\
\hline
\end{tabular}


TABLE 2 | Continued

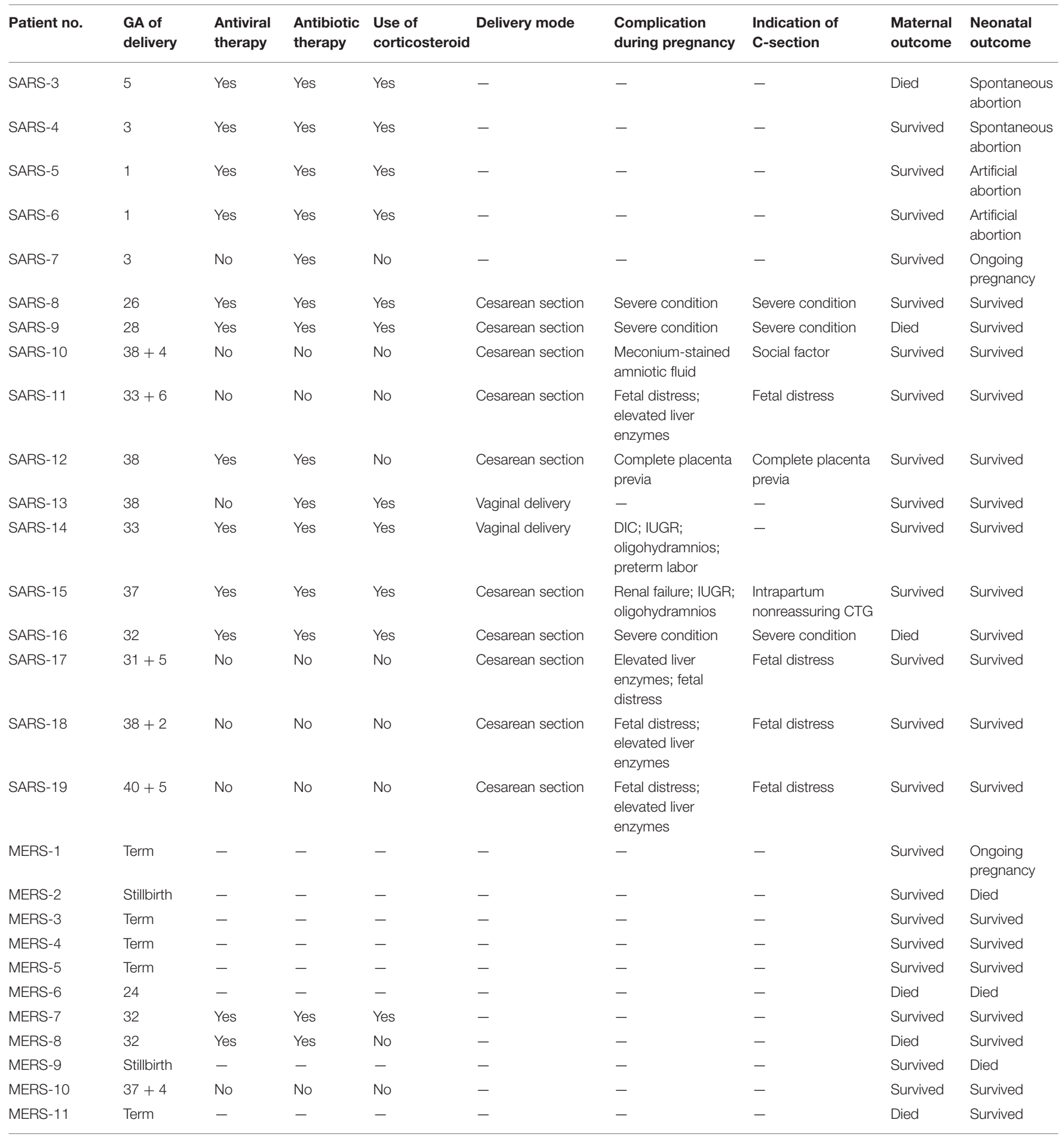

GA, gestational age; COVID-19, 2019 novel coronavirus disease; SARS, severe acute respiratory syndrome coronavirus; MERS, Middle East Respiratory Syndrome coronavirus; CT, computed tomography; CTG, cardiotocography; PROM, premature rupture of membranes; DIC, disseminated intravascular coagulation; IUGR, intrauterine growth retardation; -, no data.

termination, cesarean section is recommended (National Health Commission of the People's Republic of China, 2020). However, if the pregnant woman's condition does not worsen, there is a chance of having a healthy baby if pregnancy is continued. In the previous literature, pregnant women with SARS or MERS who continued pregnancy after their etiological test turned negative 
had favorable maternal and neonatal outcomes. However, some of them had suffered intrauterine growth restriction (IUGR), meconium-stained amniotic fluid, or fetal distress.

Pathological examination of placentas from women with COVID-19 showed various degrees of fibrin deposition inside and around the villi with local syncytial nodules, concomitant with the morphology of chorionic hemangioma or massive placental infarction (Chen S. et al., 2020). Further, the results from SARS-related pregnancies revealed increased intervillous, subchorionic fibrin, or extensive fetal thrombotic vasculopathy (Ng et al., 2006). It was speculated that these placental pathological morphological changes were caused by hypoxia during coronavirus infection, and they may result in IUGR, meconium-stained amniotic fluid, or fetal distress. Similarly, miscarriage and stillbirth could also result from hypoxia caused by coronavirus infection. Therefore, pregnant women with COVID-19 should be closely monitored, even after their nucleic acid test for SARS-Cov-2 turns negative.

In the studies included in our literature review, all pregnant women with COVID-19 and their neonates survived except for one neonate (Zhu et al., 2020). However, several pregnant women with SARS or MERS died or had a stillbirth, and some neonates failed to survive. It is speculated that COVID19 during pregnancy might be less severe than SARS or MERS during pregnancy. This is consistent with the conclusion that the mortality rate of COVID-19 is less than that of SARS or MERS (Han et al., 2020; Liao et al., 2020).

Amniotic fluid, cord blood, placenta, and the fetal membrane from pregnant women with COVID-19, SARS, and MERS were all negative when tested with a viral nucleic acid test for SARSCoV-2, SARS-CoV-1, and MERS-CoV, respectively, in the studies included in our literature review. This could be partly explained by the different distribution of their cellular receptors. The ACE2 protein is mainly expressed on lung alveolar epithelial cells and enterocytes of the small intestine (Hamming et al., 2004). However, ACE2 mRNA expression was found to be low

\section{REFERENCES}

Agostini, M. L., Andres, E. L., Sims, A. C., Graham, R. L., Sheahan, T. P., Lu, X., et al. (2018). Coronavirus susceptibility to the antiviral remdesivir (GS-5734) is mediated by the viral polymerase and the proofreading exoribonuclease. MBio 9, e00221-e00218. doi: 10.1128/mBio.00221-18

Alfaraj, S. H., Al-Tawfiq, J. A., and Memish, Z. A. (2019). Middle East Respiratory Syndrome Coronavirus (MERS-CoV) infection during pregnancy: report of two cases and review of the literature. J. Microbiol. Immunol. Infect. 52, 501-503. doi: 10.1016/j.jmii.2018.04.005

Alserehi, H., Wali, G., Alshukairi, A., and Alraddadi, B. (2016). Impact of Middle East Respiratory Syndrome coronavirus (MERS-CoV) on pregnancy and perinatal outcome. BMC Infect. Dis. 16:105. doi: 10.1186/s12879-016-1437-y

Assiri, A., Abedi, G. R., Al Masri, M., Bin Saeed, A., Gerber, S. I., and Watson, J. T. (2016). Middle East Respiratory Syndrome Coronavirus infection during pregnancy: a report of 5 cases from Saudi Arabia. Clin. Infect. Dis. 63, 951-953. doi: $10.1093 / \mathrm{cid} / \mathrm{ciw} 412$

Blaising, J., Polyak, S. J., and Pecheur, E. I. (2014). Arbidol as a broad-spectrum antiviral: an update. Antiviral Res. 107, 84-94. doi: 10.1016/j.antiviral.2014.04.006 in cells from the early maternal-fetal interface with single-cell RNA-sequencing technology. Hence, it is speculated that the ratio of SARS-CoV-2-infected mother-to-fetus transmission will be relatively low (Zheng et al., 2020). Even if SARS-CoV-2 could not transmit from mothers to babies, it could be transmitted by close contact because coronavirus also exists in the sweat glands and the distal convoluted tubules of the kidney in addition to the intestinal and respiratory tracts (To and Lo, 2004; Zhou et al., 2017). Therefore, the neonates of pregnant women with COVID19 should be isolated for at least 14 days and should not be breastfed (National Health Commission of the People's Republic of China, 2020).

\section{CONCLUSION}

This research has provided some strategies for the obstetric management of pregnant women with COVID-19. To some extent, clinical characteristics were similar among pregnancies with COVID-19, SARS, and MERS. It seems that COVID-19 during pregnancy is milder than SARS and MERS during pregnancy. However, pregnant women with COVID-19 should be closely monitored, even after their etiological tests turn negative. Maternal separation is necessary even if there was no vertical transmission. Interferon-alpha, lopinavirritonavir, and chloroquine could be good candidates for the treatment of COVID-19 during pregnancy, but more work is needed to explore their effectiveness and safety. In addition, remdesivir and arbidol, which are potential drug treatments for COVID-19, require further research on their safety during pregnancy.

\section{AUTHOR CONTRIBUTIONS}

YL and DL provided the concept. YM drafted the manuscript. SW, XL, and YP revised the manuscript. XY collected the data. All authors approved the final version for publication.

Bulgakova, V. A., Poromov, A. A., Grekova, A. I., Pshenichnaya, N. Y., Selkova, E. P., Lvov, N. I., et al. (2017). Pharmacoepidemiological study of the course of influenza and other acute respiratory viral infections in risk groups. Ter Arkh 89, 62-71. doi: 10.17116/terarkh201789162-71

Chan, J. F., Kok, K. H., Zhu, Z., Chu, H., To, K. K., Yuan, S., et al. (2020) Genomic characterization of the 2019 novel human-pathogenic coronavirus isolated from a patient with atypical pneumonia after visiting Wuhan. Emerg. Microbes Infect. 9, 221-236. doi: 10.1080/22221751.2020.1719902

Chan, J. F., Yao, Y., Yeung, M. L., Deng, W., Bao, L., Jia, L., et al. (2015). Treatment with lopinavir/ritonavir or interferon-betalb improves outcome of MERS-CoV infection in a nonhuman primate model of common marmoset. J. Infect. Dis. 212, 1904-1913. doi: 10.1093/infdis/jiv392

Chen, H., Guo, J., Wang, C., Luo, F., Yu, X., Zhang, W., et al. (2020). Clinical characteristics and intrauterine vertical transmission potential of COVID-19 infection in nine pregnant women: a retrospective review of medical records. Lancet. doi: 10.1016/ S0140-6736(20)30360-3,10.1016/s0140-6736(20)30360-3

Chen, S., Huang, B., Luo, D. J., Li, X., Yang, F., Zhao, Y., et al. (2020). Pregnant women with new coronavirus infection: a clinical characteristics and placental pathological analysis of three cases. Zhonghua Bing Li Xue Za Zhi 49:E005. doi: 10.3760/cma.j.cn112151-20200225-00138 
Chu, C. M., Cheng, V. C., Hung, I. F., Wong, M. M., Chan, K. H., Chan, K. S., et al. (2004). Role of lopinavir/ritonavir in the treatment of SARS: initial virological and clinical findings. Thorax 59, 252-256. doi: 10.1136/ thorax.2003.012658

Cinatl, J., Morgenstern, B., Bauer, G., Chandra, P., Rabenau, H., and Doerr, H. W. (2003). Treatment of SARS with human interferons. Lancet 362, 293-294. doi: 10.1016/s0140-6736(03)13973-6

Cohan, D., Natureeba, P., Koss, C. A., Plenty, A., Luwedde, F., Mwesigwa, J., et al. (2015). Efficacy and safety of lopinavir/ritonavir versus efavirenz-based antiretroviral therapy in HIV-infected pregnant Ugandan women. AIDS 29, 183-191. doi: 10.1097/QAD.0000000000000531

Divala, T. H., Mungwira, R. G., Mawindo, P. M., Nyirenda, O. M., Kanjala, M., Ndaferankhande, M., et al. (2018). Chloroquine as weekly chemoprophylaxis or intermittent treatment to prevent malaria in pregnancy in Malawi: a randomised controlled trial. Lancet Infect. Dis. 18, 1097-1107. doi: 10.1016/s1473-3099(18)30415-8

Falzarano, D., de Wit, E., Martellaro, C., Callison, J., Munster, V. J., and Feldmann, H. (2013a). Inhibition of novel beta coronavirus replication by a combination of interferon-alpha2b and ribavirin. Sci. Rep. 3:1686. doi: 10.1038/srep01686

Falzarano, D., de Wit, E., Rasmussen, A. L., Feldmann, F., Okumura, A., Scott, D. P., et al. (2013b). Treatment with interferon-alpha2b and ribavirin improves outcome in MERS-CoV-infected rhesus macaques. Nat. Med. 19, 1313-1317. doi: $10.1038 / \mathrm{nm} .3362$

Goodnight, W. H., and Soper, D. E. (2005). Pneumonia in pregnancy. Crit. Care Med.33,S390-397. doi: 10.1097/01.ccm.0000182483.24836.66

Hamming, I., Timens, W., Bulthuis, M. L., Lely, A. T., Navis, G., and van Goor, H. (2004). Tissue distribution of ACE2 protein, the functional receptor for SARS coronavirus. A first step in understanding SARS pathogenesis. J. Pathol. 203, 631-637. doi: 10.1002/path.1570

Han, Q., Lin, Q., Jin, S., and You, L. (2020). Recent insights into 2019-nCoV: a brief but comprehensive review. J. Infect. doi: 10.1016/j.jinf.2020.02.010

Holshue, M. L., DeBolt, C., Lindquist, S., Lofy, K. H., Wiesman, J., Bruce, H., et al. (2020). First case of 2019 novel coronavirus in the United States. N. Engl. J. Med. doi: 10.1056/NEJMoa2001191

Hui, D. S., Azhar, E. I., Madani, T. A., Ntoumi, F., Kock, R., Dar, O., et al. (2020). The continuing SARS-CoV-2 epidemic threat of novel coronaviruses to global health-the latest 2019 novel coronavirus outbreak in Wuhan, China. Int. J. Infect. Dis. 91, 264-266. doi: 10.1016/j.ijid.2020.01.009

Khamitov, R. A., Loginova, S., Shchukina, V. N., Borisevich, S. V., Maksimov, V. A., and Shuster, A. M. (2008). Antiviral activity of arbidol and its derivatives against the pathogen of severe acute respiratory syndrome in the cell cultures. Vopr. Virusol. 53, 9-13.

Lam, C. M., Wong, S. F., Leung, T. N., Chow, K. M., Yu, W. C., Wong, T. Y., et al. (2004). A case-controlled study comparing clinical course and outcomes of pregnant and non-pregnant women with severe acute respiratory syndrome. BJOG 111, 771-774. doi: 10.1111/j.1471-0528.2004.00199.x

Liao, X. L., Wang, B., and Kang, Y. (2020). Novel coronavirus infection during the 2019-2020 epidemic: preparing intensive care units-the experience in Sichuan Province, China. Intensive Care Med. doi: 10.1007/s00134-02005954-2

Lu, H. (2020). Drug treatment options for the 2019-new coronavirus (SARS-CoV2). Biosci. Trends 14, 69-71. doi: 10.5582/bst.2020.01020

Lu, R., Zhao, X., Li, J., Niu, P., Yang, B., Wu, H., et al. (2020). Genomic characterisation and epidemiology of 2019 novel coronavirus: implications for virus origins and receptor binding. Lancet 395, 565-574. doi: 10.1016/s0140-6736(20)30251-8

Malik, A., El Masry, K. M., Ravi, M., and Sayed, F. (2016). Middle East Respiratory Syndrome Coronavirus during pregnancy, Abu Dhabi, United Arab Emirates, 2013. Emerging Infect. Dis. 22, 515-517. doi: 10.3201/eid2203.151049

Mer, M., and Richards, G. A. (1998). Corticosteroids in life-threatening varicella pneumonia. Chest 114, 426-431. doi: 10.1378/chest.114.2.426

Minskaia, E., Hertzig, T., Gorbalenya, A. E., Campanacci, V., Cambillau, C., Canard, B., et al. (2006). Discovery of an RNA virus 3'->5' exoribonuclease that is critically involved in coronavirus RNA synthesis. Proc. Natl. Acad. Sci. U. S. A. 103, 5108-5113. doi: 10.1073/pnas.0508200103

Morra, M. E., Van Thanh, L., Kamel, M. G., Ghazy, A. A., Altibi, A. M. A., Dat, L. M., et al. (2018). Clinical outcomes of current medical approaches for Middle East respiratory syndrome: a systematic review and meta-analysis. Rev. Med. Virol. 28:e1977. doi: 10.1002/rmv.1977
National Health Commission of the People's Republic of China (2020). The Notice of Launching Guideline on Diagnosis and Treatment of the Novel Coronavirus Pneumonia (NCP), 7th edn. Available online at: http://www.nhc.gov.cn/yzygj/ s7653p/202003/46c9294a7dfe4cef80dc7f5912eb1989.shtml (accessed March 3, 2020).

Ng, W. F., Wong, S. F., Lam, A., Mak, Y. F., Yao, H., Lee, K. C., et al. (2006). The placentas of patients with severe acute respiratory syndrome: a pathophysiological evaluation. Pathology 38, 210-218. doi: 10.1080/ 00313020600696280

Park, M. H., Kim, H. R., Choi, D. H., Sung, J. H., and Kim, J. H. (2016). Emergency cesarean section in an epidemic of the middle east respiratory syndrome: a case report. Korean J. Anesthesiol. 69, 287-291. doi: 10.4097/kjae.2016.69.3.287

Payne, D. C., Iblan, I., Alqasrawi, S., Al Nsour, M., Rha, B., Tohme, R. A., et al. (2014). Stillbirth during infection with Middle East respiratory syndrome coronavirus. J. Infect. Dis. 209, 1870-1872. doi: 10.1093/infdis/jiu068

Roberts, S. S., Martinez, M., Covington, D. L., Rode, R. A., Pasley, M. V., and Woodward, W. C. (2009). Lopinavir/ritonavir in pregnancy. J. Acquir. Immune Defic. Syndr. 51, 456-461. doi: 10.1097/QAI.0b013e3181a2813f

Robertson, C. A., Lowther, S. A., Birch, T., Tan, C., Sorhage, F., Stockman, L., et al. (2004). SARS and pregnancy: a case report. Emerging Infect. Dis. 10, 345-348. doi: 10.3201/eid1002.030736

Sheahan, T. P., Sims, A. C., Graham, R. L., Menachery, V. D., Gralinski, L. E., Case, J. B., et al. (2017). Broad-spectrum antiviral GS-5734 inhibits both epidemic and zoonotic coronaviruses. Sci. Transl. Med. 9:396. doi: 10.1126/scitranslmed.aal3653

Sheahan, T. P., Sims, A. C., Leist, S. R., Schafer, A., Won, J., Brown, A. J., et al. (2020). Comparative therapeutic efficacy of remdesivir and combination lopinavir, ritonavir, and interferon beta against MERS-CoV. Nat. Commun. 11:222. doi: 10.1038/s41467-019-13940-6

Shen, L., Yang, Y., Ye, F., Liu, G., Desforges, M., Talbot, P. J., et al. (2016). Safe and sensitive antiviral screening platform based on recombinant human coronavirus OC43 expressing the luciferase reporter gene. Antimicrob. Agents Chemother. 60, 5492-5503. doi: 10.1128/aac.00814-16

Stockman, L. J., Bellamy, R., and Garner, P. (2006). SARS: systematic review of treatment effects. PLoS Med. 3:e343. doi: 10.1371/journal.pmed.0030343

To, K. F., and Lo, A. W. (2004). Exploring the pathogenesis of severe acute respiratory syndrome (SARS): the tissue distribution of the coronavirus (SARS$\mathrm{CoV}$ ) and its putative receptor, angiotensin-converting enzyme 2 (ACE2). J. Pathol. 203, 740-743. doi: 10.1002/path.1597

Totura, A. L., and Bavari, S. (2019). Broad-spectrum coronavirus antiviral drug discovery. Expert Opin. Drug Discov. 14, 397-412. doi: 10.1080/17460441.2019.1581171

Villegas, L., McGready, R., Htway, M., Paw, M. K., Pimanpanarak, M., Arunjerdja, R., et al. (2007). Chloroquine prophylaxis against vivax malaria in pregnancy: a randomized, double-blind, placebo-controlled trial. Trop. Med. Int. Health. 12, 209-218. doi: 10.1111/j.1365-3156.2006.01778.x

Vincent, M. J., Bergeron, E., Benjannet, S., Erickson, B. R., Rollin, P. E., Ksiazek, T. G., et al. (2005). Chloroquine is a potent inhibitor of SARS coronavirus infection and spread. Virol. J. 2:69. doi: 10.1186/1743-422X-2-69

Wang, M., Cao, R., Zhang, L., Yang, X., Liu, J., Xu, M., et al. (2020a). Remdesivir and chloroquine effectively inhibit the recently emerged novel coronavirus (SARS-CoV-2) in vitro. Cell Res. 30, 269-271. doi: 10.1038/s41422-020-0282-0

Wang, Z., Chen, X., Lu, Y., Chen, F., and Zhang, W. (2020b). Clinical characteristics and therapeutic procedure for four cases with 2019 novel coronavirus pneumonia receiving combined Chinese and Western medicine treatment. Biosci. Trends doi: 10.5582/bst.2020. 01030

Ward, S. A., Sevene, E. J., Hastings, I. M., Nosten, F., and McGready, R. (2007). Antimalarial drugs and pregnancy: safety, pharmacokinetics, and pharmacovigilance. Lancet Infect. Dis. 7, 136-144. doi: 10.1016/s1473-3099(07)70025-7

Wong, S. F., Chow, K. M., and de Swiet, M. (2003). Severe Acute Respiratory Syndrome and pregnancy. BJOG 110, 641-642. doi: 10.1046/j.1471-0528.2003.03008.x

Wong, S. F., Chow, K. M., Leung, T. N., Ng, W. F., Ng, T. K., Shek, C. C., et al. (2004). Pregnancy and perinatal outcomes of women with severe acute respiratory syndrome. Am. J. Obstet. Gynecol. 191, 292-297. doi: 10.1016/j.ajog.2003.11.019 
Yazdani Brojeni, P., Matok, I., Garcia Bournissen, F., and Koren, G. (2012). A systematic review of the fetal safety of interferon alpha. Reprod. Toxicol. 33, 265-268. doi: 10.1016/j.reprotox.2011.11.003

Yu, N., Li, W., Kang, Q., Xiong, Z., Wang, S., Lin, X., et al. (2020). Clinical features and obstetric and neonatal outcomes of pregnant patients with COVID-19 in Wuhan, China: a retrospective, single-centre, descriptive study. Lancet Infect. Dis. 20, 559-564. doi: 10.1016/s1473-3099(20)30176-6

Yudin, M. H., Steele, D. M., Sgro, M. D., Read, S. E., Kopplin, P., and Gough, K. A. (2005). Severe acute respiratory syndrome in pregnancy. Obstet. Gynecol. 105, 124-127. doi: 10.1097/01.AOG.0000151598.49129.de

Zhang, J. P., Wang, Y. H., Chen, L. N., Zhang, R., and Xie, Y. F. (2003). Clinical analysis of pregnancy in second and third trimesters complicated severe acute respiratory syndrome. Zhonghua Fu Chan Ke Za Zhi 38, 516-520.

Zhao, R.h., Wang, H., Xu, K. J., and Sheng, J. F. (2020). Pregnancy with 2019 Novel Coronavirus: a case report. Zhejiang Med. J. 42, 303-317. doi: 10.12056/j.issn.1006-2785.2020.42.3.2020-237

Zheng, Q. L., D. T., and Jin, L. P. (2020). Single-cell RNA expression profiling of ACE2 and AXL in the human maternal-Fetal interface. Reprod. Dev. Med. 4, 7-10. doi: 10.1093/infdis/130.5.502
Zhou, J., Li, C., Zhao, G., Chu, H., Wang, D., Yan, H. H., et al. (2017). Human intestinal tract serves as an alternative infection route for Middle East respiratory syndrome coronavirus. Sci. Adv. 3:eaao4966. doi: 10.1126/sciadv.aao4966

Zhu, H., Wang, L., Fang, C., Peng, S., Zhang, L., Chang, G., et al. (2020). Clinical analysis of 10 neonates born to mothers with 2019-nCoV pneumonia. Transl. Pediatr. 9, 51-60. doi: 10.21037/tp.2020.02.06

Conflict of Interest: The authors declare that the research was conducted in the absence of any commercial or financial relationships that could be construed as a potential conflict of interest.

Copyright (c) $2020 \mathrm{Mei}$, Luo, Wei, Liao, Pan, Yang and Lin. This is an open-access article distributed under the terms of the Creative Commons Attribution License (CC $B Y)$. The use, distribution or reproduction in other forums is permitted, provided the original author(s) and the copyright owner(s) are credited and that the original publication in this journal is cited, in accordance with accepted academic practice. No use, distribution or reproduction is permitted which does not comply with these terms. 